\title{
Subglacial water-sheet floods, drumlins and ice-sheet lobes
}

\author{
E. M. Shoemaker \\ Applied and Computational Mathematics Program, Simon Fraser University, Burnaby, British Columbia V5A 1S6, Canada
}

\begin{abstract}
ABSIRACT. The effect of subglacial lakes upon ice-sheet topography and the velocity patterns of subglacial watcr-shect floods is investigated. A subglacial lake in the combined Michigan-Green Bay basin, Grcat Lakes, North America, lcads to: (1) an icc-sheet lobe in the lee of Lake Michigan; (2) a change in orientations of flood velocities across the site of a supraglacial trough aligned closely with Green Bay, in agreement with drumlin orientations; (3) low water velocities in the lee of Lake Michigan where drumlins are absent; and (4) drumlinization occurring in rcgions of predicted high watcr velocities. The extraordinary divergence of drumlin orientations ncar Lake Ontario is explained by the presence of subglacial lakes in the Ontario and Erie basins, along with ice-sheet displacements of up to $30 \mathrm{~km}$ in eastern Lake Ontario. The megagrooves on the islands in western Lake Erie are likely to be the product of the late stage of a water-sheet flood when outflow from eastern Lake Ontario was dammed by displaced ice and instead flowed westward along the Erie basin. The Finger Lakes of northern New York statc, northeastern U.S.A., occur in a region of likely icc-shect grounding where water shects became channelized. Green Bay and Grand Traverse Bay are probably the products of crosion along paths of strongly convergent water-sheet flow.
\end{abstract}

\section{INTRODUCTION}

The idea of subglacial water-sheet floods is highly controversial, as is the connection made between floods and drumlin formation. 'The lattcr controversy reduces to two conflicting tenets: the conventional, that drumlins are streamlined forms molded by laminar ice flow, and the heretical, that drumlins are the product of turbulent water flow. The two points of view have as much in common as creationism and evolutionism.

I find the water-sheet model compelling on the basis of field evidence and (recent) theory. Perhaps the strongest field evidence supporting the fluvial model is the decailcd shapes of erosional marks in rock, particularly hairpinshaped grooves. Hairpin scours are interpreted as the product of debris-laden horseshoe-shaped vortices which form around obstacles (Dargahi, 1990). This idca was previously and subsequently applied to explain erosional marks on glacial beds for a wide range of scales (Shaw and Sharpe, 1987; Shaw, 1988, 1994; Sharpe and Shaw, 1989; Shaw and others, 1989; Kor and others, 1991). The initial inspiration for this model is due to Allen $(1971,1982)$ who verified experimentally that erosional forms such as are seen on a glacier bed are produced by separated turbulent fluid flow. Shaw (1994) examined in detail the genesis of hairpin crosional scours. The weight of evidence supports the fluvial model. The genetic relationship between hairpin scours and certain types of erosional drumlins has been made (Shaw and Sharpe, 1987; Sharpe and Shaw, 1989; Shaw, 1994).

Hundreds of pages of field evidence have appeared supporting water-sheet floods and their linkage to various erosional and depositional landforms. (See Shaw (1996) for a review.) Far from eliciting controversy, this cvidence has simply been ignored. No detailed examination of field evidence is given here.
The theoretical underpinnings of the fluvial model are a more recent development. Shoemaker (1991) showed how large subglacial lakes, the presumed water source for at least some floods (supraglacial lakes may have been the water source for others), can form bencath ice sheets and how subglacial ponding reduces the ice-surface gradient. Of relevance is the recent evidence that one of the Antarctic subglacial lakes (Vostok) is much larger than previously thought, about the size of Lake Ontario (Kapitsa and others, 1996). During a period of rapid deglaciation, a large supraglacial lake can create temperate ice beneath it. The possibility exists of catastrophic drainage from such a lake through temperatc icc to a subglacial lake (Shocmaker, 1991). This implies that subglacial lakes beneath a deglaciating Laurentide ice sheet could have collected water much more rapidly than contemporary Antarctic subglacial lakes.

The concept and mechanics of subglacial water-sheet floods were considered by Shoemaker (1992b). Reasons were given why a flood can take the form of a sheet rather than the well-studied, and acceptcd, tunncl form (Nye, 1976). Ice lift-off, with grounding only on bed highs, over a corridor hundreds of $\mathrm{km}$ long and at least $100 \mathrm{~km}$ wide causes rapid ice elongation or a surge (Shoemaker, 1992b). If this corridor reaches the terminus, an ice-sheet lobe results (Shocmaker, 1992a). Icc-shect lobes are generally attributed to surges. For example, Kemmis (1991) attributes advances of the Des Moines Lobe, Iowa, U.S.A., to surges.

The criticism that watcr-shcet floods cannot occur because sheet flow is unstable (Walder, 1982, 1994) was refuted by Shoemaker (1994) who showed that turbulence greatly increases the characteristic time for the viability of an "unstable" water sheet. A water sheet metcrs thick can exist for the order of a month or more.

Shaw and others (1989) calculated that a flood volume of the order of $84000 \mathrm{~km}^{3}$ was required to form the Livingstone 
Lake (Saskatchewan, Canada) ficld of depositional drumlins. Flood volumes of this magnitude have raised much skcpticism. The calculation assumes that the drumlin molds or cavities in the basal ice are melted by heat generated from water flow (Shaw, 1983). Shoemaker (1995) showed that these cavities were more likely to be abraded by suspended scdiment in highly turbulent flows. Corrasion by sand blasting is much more efficient than melting. Estimates of flood volumes cannot be made, but they could easily be at least an order of magnitude less than $84000 \mathrm{~km}^{3}$.

Finally, corrasion of basal ice and bed erosion increase non-linearly with water-shect vclocitics (Shoemaker, 1995). The inference from the fluvial model is that both depositional and erosional drumlins should tend to exist in those regions where water-shect velocitics arc high, and should be absent in regions where velocities are very low.

This paper utilizes the idea that subglacial lakes affect the ice-sheet topography. The topography, in turn, has a major influence upon the subglacial hydraulic gradicnt during a water-sheet flood and the accompanying velocity field. By assuming the existence of subglacial lakes in major basins, such as certain of the Great Lakes, North America, it is possible to identify regions of potentially high and low water-sheet velocities near these subglacial lakes. If drumlins occur in regions of predicted high velocity and are absent from regions of predicted low velocity, the fluvial model gains credibility. If the result is contrary, the fluvial model must be rejected. Of course, if a particular basin did not contain a subglacial lake at the time of a flood, the predictions of a fluvial model based upon the assumption of a lake are inapplicable and this fact should become apparent when theory is compared with ficld observations.

The qualitative effect of a subglacial lake in the Iake Michigan basin is first investigated. Many prominent drumlin fields are situated nearby, and there are large areas where drumlins are absent. This suggests that a subglacial lake may have influenced a water shect. An icc-sheet lobe is a by-product of this initial investigation. Conclusions are drawn regarding the influence of subglacial lakes in the Superior and Huron basins upon drumlin-field locations.

The situation near Lakes Ontario and Erie is considered. Here, the influence of bed topography and ice displacement is considered, as well as subglacial lakes. Consideration is given to fluvial erosion in the genesis of lake basins. Many drumlin fields occur where it is unlikely that the ice-sheet topography was unusual. Two examples are given illustrating why this need not be inconsistent with the fluvial model.

\section{EFFECT OF SUBGLACIAL LAKES UPON ICE-SHEET TOPOGRAPHY}

Because the basal-ice shear stress, $\tau_{\mathrm{b}}$, vanishes on a subglacial lake, the classical result (Paterson, 1994, p. 240) relating $\mathcal{T}_{b}$ to ice thickness, $h$, and the magnitude, $\alpha$, of the iccsurface gradient,

$$
\tau_{\mathrm{b}}=\rho g h \sin \alpha
$$

predicts a horizontal ice surface (ice lid) over the lake. Howcver, Equation (l) necd not apply in regions of diameter the order of $h$, or less. Siegert and Ridley (1998) found that Antarctic subglacial lakes, with mean dimension exceeding thrce times the ice thickness, expressed thcir prescnce by reduced surface slopes, at least an order of magnitude less than $\alpha$ above neighboring grounded ice. Lakes with mean dimension no greater than the ice thickness did not significantly affect the icc-surface morphology. The ice lid over the Vostok subglacial lake has $\alpha<7 \times 10^{-5}$. Accordingly, for most (but not all) purposes it is reasonable to assume $\alpha=0$ on an ice lid over a subglacial lake occupying the Lake Michigan basin, for example.

\section{Ice topography near an idealized subglacial Lake Michigan, constant $\tau_{\mathbf{b}}$}

Figure 1 shows half of an idealized symmetric rectangular lake $\mathrm{ABCD}$ with $\mathrm{AB}$ the center line. The aspect ratio $|\Lambda \mathrm{B}|$ $2|\mathrm{BC}|$ is five, the approximate aspect ratio of Lake Michigan. Assume that the ice-lid surface is horizontal and the spccific discharge $\mathrm{q}^{*}\left(\mathrm{~m}^{2} \mathrm{~s}^{-1}\right)$ (flux) up-glacier from the lake is uniform and in the direction shown. The ice-sheet topography is then symmetric about $\mathrm{ABG}$. Let FJ represent the position of the terminus away from the influence of the lake. This is the approximate position of the Laurentide terminus between $18000 \mathrm{BP}$ and, perhaps, $15000 \mathrm{BP}$ (Dyke and Prest, 1987), when Lake Michigan was ice-covered. It is easy to sketch the ice-shect topography for other terminus positions once the construction is understood.

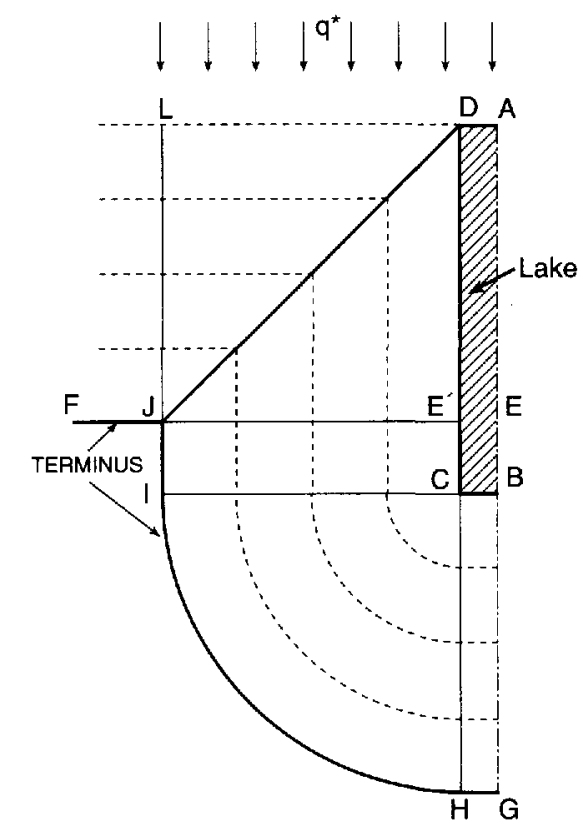

Fig. I. Influence of idealized subglacial lake upon ice sheet (contour lines dashed) assuming constant ice-surface gradient $\alpha . F J E$, terminus in absence of lake. $D J$ is a trough and $\angle D A B C D$ is at constant elevation. $A G$ is a line of symmetry. $q^{*}$ is the uniform ice flux up-glacier.

If $\tau_{b}$, is assumed constant bencath grounded ice the icc topography is unique and easily constructed. The best approach is to first assume that $\alpha$ is constant in Equation (1). The cqually spaced dashed lines in Figure 1 are ice contour lines. LDJL and DCIJD are planes sloping downward in the direction of $L_{J}$ and $E^{\prime} J$, respectively. $D J$ is a straight-line trough. Region CHIC is conical and BGHCB is a plane. Lines $\mathrm{DG}$ and $\mathrm{BG}$ are ridges.

Now consider the ice topography if $\tau_{b}$ is constant in Equation (1) and the terminus remains at FJ. Although the contour lines are not equally spaced and regions LDJL, DCIJD and BGHCB are not planes, the plan view of the so- 
lid lines in Figure 1 is unchanged. DJ is still a trough, although it stcepens from $\mathrm{D}$ to J. $\alpha$ is infinitc at the terminus. It is important to recognize that the ice lid is a plateau elevated hundreds of meters above point $\mathrm{J}$, for example. This conventional, $\tau_{\mathrm{b}}=$ constant, model produces an icc-shect lobe EGJE of length $|\mathrm{EG}|$ equal to the length of the lake. The lobe aspect ratio $|\mathrm{EG}| / 2 \mid \mathrm{EJ} /$ depends upon the position of the terminus FJ.

In this and later cxamples a scal, as discussed by Nyc (1976) and Shoemaker (1992a), of locally elevated ice near the ice-lid grounding line is not shown around the elevated portion of ice lids. A complete scal must be present unless the subglacial lake is on the verge of catastrophic discharge.

Figure 1 is satisfactory in illustrating qualitative aspects of the ice-sheet topography, but unsatisfactory if mass conservation is considered. (In all considerations of mass conservation the arguments are qualitative and ignore accumulation and ablation.) The assumed uniform ice flux $\mathrm{q}^{*}$ far up-glacier applies on line LA because, with LA at constant elevation, the presence of the lake is not felt there. 'The ice beneath LDJL is supplied by the ice discharge across DL. The much larger ice volume beneath DJG $\Lambda \mathrm{D}$ is supplied by the smaller ice discharge across $\mathrm{AD}$, a contradiction. Thus, the $\tau_{\mathrm{b}}=$ constant assumption must be modified once mass conservation is considered.

\section{Existence of a lobe}

Figure l suggests that for an ice sheet that has not necessarily undergone a recent surge, an ice lobe, nevertheless, is associated with a large-aspect-ratio subglacial lake located near a tcrminus. However, since the icc topography is incorrect in detail, one cannot conclude yet that a lobe exists. One referee suggested that the ice lid could be depressed, rather than elevated, as is the case for some Antarctic ice streams throughout most of their length (Shabtaic and Bentley, 1988, fig. 4). $\Lambda$ surge down the subglacial Lake Michigan basin could produce a depressed ice lid (but would also produce a lobe). In all subsequent developments this surge scenario is ruled out.

Assume there is no lobe in the Michigan basin case. Make the conservative assumption that the terminus is straight as in Figure 2a. Away from the influence of the lake (c.g. along $\mathrm{AB}$ ) the $\tau_{\mathrm{b}}=$ constant condition is assumed to apply. The $100 \mathrm{~m}$ contours correspond to $\tau_{\mathrm{b}}=0.16 \mathrm{bar}$. The following argument strengthens as $\tau_{b}$ increases. The value 0.16 bar is small compared to contemporary ice sheets (Paterson, 1994, p. 242) but is morc rcasonablc for warmbased ponded ice sheets (Shoemaker, 1991).

Transition zones of steep ice connect the nearly horizontal ice lid to grounded ice where the topography is unaffected by the presence of the subglacial lake. Generous transition-zone widths of $25 \mathrm{~km}$ are assumed at both $\mathrm{U}$ and $\mathrm{L}$ in Figure 2a. Transition widths are generally $<14 \mathrm{~km}$ in shear zones adjoining Antarctic ice streams and zones adjoining grounding lines (Shabtaie and Bentley, 1988).

Objections arise from this no-lobe assumption. (1) The total change in elevation in the transition zone, or zones, is about $880 \mathrm{~m}$. This is a large change to be accommodated in $50 \mathrm{~km}$ or less. If $\tau_{\mathrm{b}}>0.16$ bar this objection is magnified. (2) Enhanced flux should accompany the stecp ice at L. This, in turn, should produce a lobe. If this objection is removed by assuming that the entire ice lid is depressed, as has been suggested, then ice flows into the ice lid throughout its length.

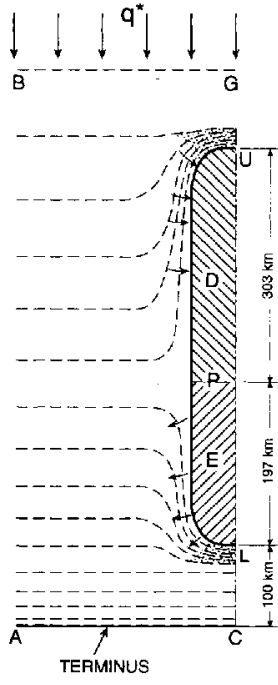

(a)

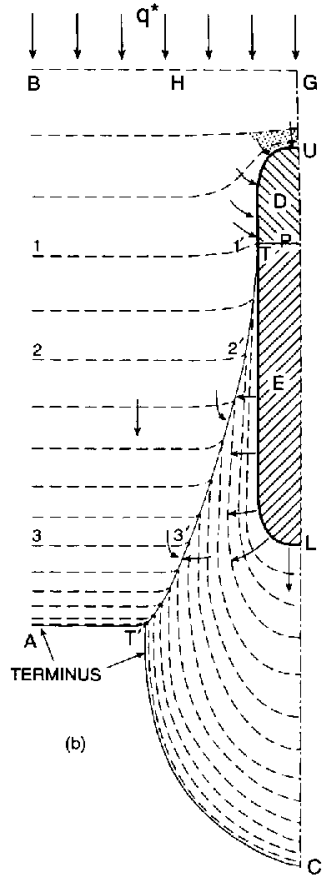

Fig. 2. Geometric argument supporting existence of lobe downglacier from idealized subglacial Lake Michigan. $100 \mathrm{~m}$ conlour lines correspond to $\tau_{\mathrm{b}}=0.16$ bar azeay from lake influence. D, depressed ice; E, elevated ice. $q^{*}$ is as in Figure 1 , and $G C$ is a line of symmetry. Transilion zones $25 \mathrm{~km}$ wide assumed at lake ends (shaded). Arrores indicate ice-flow directions. (a) No lobe. Line at $P$ chosen so that equal elevation changes of $440 \mathrm{~m}$ occur in both transition zones. (b) Lobe. Shift of line $P$ up-glacier reduces $\alpha$ in transition zone $U$ by factor of about four. Steep ice eliminated at L. Contours drawen assuming TT' is a melt channel.

Consequently the ice discharge out of the lid at $\mathrm{L}$ is very large, which contradicts both the no-lobe assumption and the absence of steep ice at L. (3) A subglacial lake is an ice conduit which offers no subglacial resistance to ice movement. It is difficult to see how a lobe cannot result from a large-aspect-ratio ice conduit residing near the terminus as in Figure 2a. (4) Many Laurentide lobes were aligned with Great Lakes basins, including the Erie-Ontario, Michigan, Superior and Huron lobes (Dyke and Prest, 1987). It could be argued that the James and Des Moines Lobes were associated with the numerous lake basins of Minnesota and southern Manitoba, including Lake Winnipeg.

These objections are removed in Figure $2 \mathrm{~b}$ where point $P$, the boundary betwecn depressed and clevated icc, is shifted towards $\mathrm{U}$. This reduces the elevation change in the transition zone at $\mathrm{U}$, the more so the closer $\mathrm{P}$ is to U. Steep ice ncar $\mathrm{L}$ is climinated. The main icc flow and ice flowing from the ice lid across TL intersect at TT'. This could be a pressure ridge but in a period of deglaciation should bc a melt-channel trough. This is reflected in the upward-turning contours at 2' and $3^{\prime}$. Upward turning at 1', 2' and $3^{\prime}$ is also increased by the fact that the ice discharge across $\mathrm{BH}$ (not HG) feeds region T1AT"T. The right portion of this region is shiclded and receives a reduced flux. $\mathrm{TT}^{\prime}$ is tangent to the ice lid at $\mathrm{T}^{\prime}$ because the ice flux from the lid vanishes there. Since the flux from the lid increases from $T$ to $L$, the trough curves as shown. The shape of $\mathrm{TT}^{\prime}$ is only suggestive and the upward curvature may not extend to $T^{\prime}$.

The location of $\mathrm{P}$ is determined by ice balance. The icc discharge on $\mathrm{BH}$ feeds the ice volume $\mathrm{V}_{1}$ beneath TIAT'T, 
The ice discharge on $\mathrm{HG}$ feeds $\mathrm{V}_{2}$ : the ice beneath TT'CLT plus the ice beneath region $\mathrm{E}$. As $\mathrm{P}$ moves towards $\mathrm{U}, \mathrm{H}$ moves towards $\mathrm{G}$, so the discharge feeding $\mathrm{V}_{2}$ decreases. The effect upon $V_{1}$ is the opposite. Point $P$ resides where the ice discharges across $\mathrm{BH}$ and $\mathrm{HG}$ are in proper proportion to $\mathrm{V}_{1}$ and $\mathrm{V}_{2}$, respectively, depending upon how close the icc sheet is to steady state. The remainder of this development does not rely upon the existence of an ice lobe, although Figure 3 is drawn assuming a lobe.

\section{Ice topography near a subglacial Lake Michigan- Green Bay, non-constant $\tau_{b}$}

Figure 3 shows the ice topography near a subglacial lake occupying idealized Lake Michigan and Green Bay basins. Symmetry is assumed about line GC. The outline of the contemporary lakes appears in Figure $\overline{3}$. It is assumed that the entire basin complex contains a lake. The consequences of this assumption are compared later with field evidence.

'The terminus $A T^{\prime}$ corrcsponds to Figure 1. Contour 1-1' is at the elevation of the ice lids. This choice of point $\mathbf{P}$ appears to render reasonable mass balance. $\tau_{\mathrm{b}}$ is set equal to $0.16 \mathrm{bar}$ on $\mathrm{AB}$ and $\mathrm{CF}$, with the contour spacings on these lines computed from Equation (1). As before, trough TT' lies within a supraglacier melt channel and marks the boundary of intersccting icc-flow fields. Segment $\mathrm{Tt}$ of the trough is a line which lies closer to the Green Bay boundary than to Lake Michigan because the ice flux from the larger Michigan lid dominates the ice flux from the smaller lid. The curve of segment $\mathrm{t}^{\prime} \mathrm{T}^{\prime}$ reflects the increasing ice flux from the Michigan ice lid as the relief increases towards D. A minor trough issuing from point $\mathrm{l}^{\prime}$ is not shown.

Once $\tau_{\mathrm{b}}, \mathrm{P}$ and $\mathrm{TT}^{\prime}$ are chosen, the qualitative character of Figure 3 is determined. Details which are indeterminate include the shape of the contours near the trough, which depends upon the extent of melting by surface runoff and the effect of ice flow from the Green Bay ice lid upon the Green

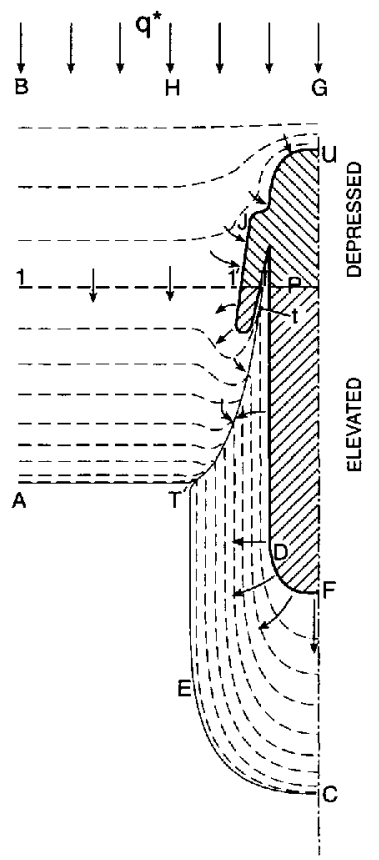

Fig. 3. Contours near idealized Lake Michigan Green Bay subglacial lake. Ice discharge across $H G$ feeds ice lids and lobes. $\tau_{\mathrm{b}}=0.16$ bar along $A B$ and $C F$. Contours drawn assuming trough TT is a melt channel.
Bay "lobe". This Green Bay discharge can also influence the shape of the terminus $A^{\prime}$. Note that $\alpha$ is relatively large on the flanks of the ice lids. As drawn, $\tau_{\mathrm{b}}$ achieves values up to 0.8 bar.

\section{Regions of high and low velocity}

Figure 3 can be used to determine regions of high and low velocities for a water sheet passing beneath the ice profile. Assuming uniform flow along a flowline, which is adequatc here, $V$ satisfies

$$
V=m^{\frac{33}{10}} q^{\frac{2}{5}} / 2^{\frac{2}{5}} n^{\frac{3}{5}}
$$

(Shoemaker, 1995). Here, $n$ is Manning's number (SI), $q$ $\left(\mathrm{m}^{2} \mathrm{~s}^{-1}\right)$ is the specific water discharge (flux) and $m$, in the terminology of open-channel flow, is a head gradient given by

$$
m=-\frac{\mathrm{d} b}{\mathrm{~d} s}-\frac{\rho}{\rho_{\mathrm{w}}} \frac{\mathrm{d} h}{\mathrm{~d} s}-\frac{\mathrm{d} y}{\mathrm{~d} s}
$$

where $\rho_{\mathrm{w}}$ is water density, $s$ is downstream distance along a flowline, $b$ is bed height above a horizontal datum and $y$ is the water-sheet thickness. Assume that $\mathrm{d} b / \mathrm{d} s=0$ except on the banks of the subglacial lakes. Take $\rho / \rho_{\mathrm{w}}=0.9$.

It is convenient to utilize the ice-surface slope in the direction of flow, $\alpha_{\mathrm{s}}$. Then, Equation (3) can be written approximately as

$$
m \approx-\alpha_{\mathrm{s}}-\frac{\mathrm{d} y}{d s} .
$$

The flow field for the subglacial water sheet is now approximately the same, and would be identical if $\rho / \rho_{w}=1$, as the flow field for a water sheet travelling on top of a fully grounded ice sheet which has supraglacial basins, averaging perhaps $100 \mathrm{~m}$ in depth, identical to and situated above the original subglacial lake basins. An openchannel supraglacial water-shect flood over this fictitious icc topography can be visualized more easily than the actual subglacial flood. However, because of ice stiffness, under conditions of rapidly varying flow a subglacial water sheet can, over short distances, behave as a confined flow, with pressure more or less than the ovcrburden pressure. For this special circumstance Equation (2) does not apply. The supraglacial flood analogy also fails locally.

There are several notable features of this fictitious supraglacial flood which is similar to a river flood, the difference being that the water which escapes laterally across the banks of the ice basins flows rapidly down the flanks of the clcvated icc lid where $m$ in Equation (2) is large (Fig. 3). (1) There is convergent fow into the depressed ice-lid region near $J U$ in Figure 3 from the ice cirque which has a relief in excess of $200 \mathrm{~m}$. Deep water in this depressed region pushes the flood southward ( $m \approx \mathrm{d} y / \mathrm{d} s$ there). Although $q$ is high in the lakc basins, $V$ is low because of the large water depth. Note that a head gradient of $10^{-4}$ along either basin axis produces a flux which is much larger than the flux produced beneath previously grounded icc by a typical head gradicnt of $10^{-3}$ and a typical water-sheet thickness of $30 \mathrm{~m}$. (2) There is strong convergent flow near the trough $\mathrm{TT}^{\prime}$ (Fig. 3) where $q$ is very high. (3) $V$ can be high on the banks of the supraglacial ice basin where $m$ values are largc. (4) A rcgion of divergent flow and low $V$ exists in DECFD. These features are sketched in Figure 4.

The pronounced change in flow direction of the fictitious supraglacial flood, and corresponding subglacial flood, near 


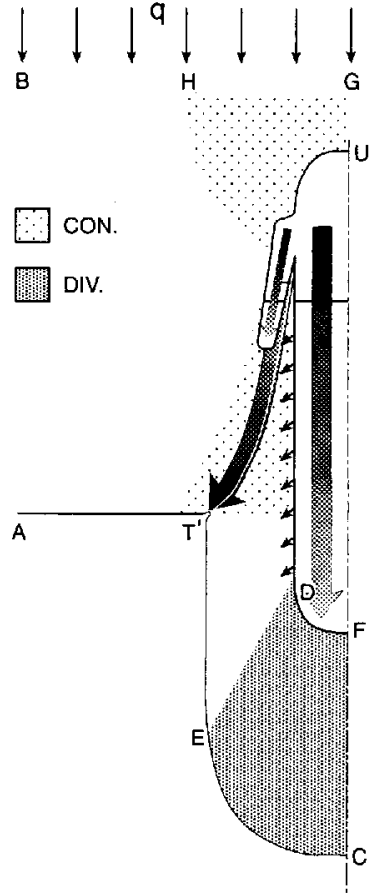

Fig. 4. Regions of high and low water-sheet Vorresponding to Figure 3. Large arrowes show major flow paths. Shading indicates flux intensity. Small arrowes show passible large Vunder ice-lid ramps. Convergent and divergent flow regions shaded.

the trough is important. Water exits the supraglacial ice basin roughly perpendicular to the basin margin. Here the dominant term in Equation (3) is $\mathrm{d} h / \mathrm{d} s$. As this water approaches the trough the flow dircction changes rapidly until it is roughly aligned with the trough. The controlling term in Equation (3) in this turning region is $-\mathrm{d} y / \mathrm{d} s$. That is, shallow water travelling down the stcep flanks of the ice basin is forced to turn by deep water in the ice trough.

In this interpretation it has been assumed that the ice sheet lifts off its bed but undergoes no displacement downstrcam. Ice displacements, which can greatly affect the velocity field (Shoemaker, 1995), are considered later in connection with drumlins near Lake Ontario.

\section{The extent of a subglacial lake}

$\Lambda$ the time of a water-sheet flood the extent of a subglacial lake in any basin is unknown. A subglacial lake grows until, normally, it discharges some or most of its volume by an outburst flood (Shoemaker, 1991). One cannot determine theoretically the state of any particular subglacial lake within its filling-discharge cycle at the time of a subglacial watersheet flood. Because the size of a horizontal ice lid is determincd by the size of the subglacial lakc, the ice-sheet topography near subglacial basins is theoretically indeterminate.

'Two additional unknowns can limit the maximum extent of a subglacial lake, particularly in a large basin. If local isostatic equilibrium is attained, ice depresses bedrock by about one-third the ice thickness. However, the time duration of an ice lid over a subglacial lake is almost certainly too short to achieve isostatic equilibrium. Third, there must be a small non-zero surface slope, $\alpha$, on the ice lid because the lid cannot adjust instantaneously to the input of ice in the depressed rcgion and loss of ice in the clevated region. $\alpha$ could easily be greater than $7 \times 10^{-5}$, the value for the ice surface over the large Vostok subglacial lake. Corresponding to a surface slope $\alpha$, the base of the ice lid has an adverse slopc of $\approx 11 \alpha$ (Shoemaker, 1991). The isostatic effect tends to limit the down-glacier extent of a subglacial Lake Michigan. The ice-lid subsurface gradient tends to limit the up-glacier extent. Since the two effects tend to cancel, it is conceivable that the entire Lake Michigan basin containcd a lake at the time of a water-sheet flood.

In time, we may learn how to determine the size of paleo-subglacial lakes from field evidence. Sediment is deposited where a water-sheet flood encounters the decp water of a subglacial lake. A moraine is formed. There are numerous candidates for such moraincs near the northern boundaries of the contemporary Great Lakes, including the Oak Ridges moraine north of Lake Ontario. This contains large masses of glaciofluvial and glaciolacustrine deposits (Duckworth, 1979). Note that such moraines may exist beneath contemporary lakes.

\section{Comparison with field evidence and some implica- tions}

Erosion increases with $V$ to a high power (Shoemaker, 1995). Drumlins should therefore tend to occur in the convergent flow regions (Fig. 4) as well as on the bed beneath the steep icc-lid flanks (Fig. 3). Drumlins should be absent from the divergent flow region.

Figure 5 illustrates drumlin ficlds near several of the Great Lakes. Drumlin swarms tend to congregate near the flanks of Lakes Superior, Huron, Michigan, Green Bay and Grand Traverse Bay $(T)$. The emphasis here is on the drumlins in insert a. A moraine, $\mathrm{I}$, interpreted as an interlobate moraine (Alden, 1918), appears at the approximate position of TT' in Figure 3. It is striking how this moraine marks the boundary between drumlin fields of different orientations. This is consistent with the flow field of Figure 4 if the drumlins to the east of the moraine are assumed to be formed by shcet flow beneath the stecp ice above the flank of subglacial Lake Michigan and the drumlins to the west of the moraine are the product of the main sheet flow, with this flow turning towards the trough TT'. The fluvial model suggests that this moraine may not be an interlobate moraine but rather marks the location of a supraglacial trough. The moraine could be composed of sediment deposited beneath the trough during the waning phase of a water-sheet flood when the major flood routes, carrying the last of the flood, became sediment traps.

A similar situation occurs in insert $b$, although the interpretation is less clear. $\mathrm{M}$ is part of a longer moraine (Flint and others, 1959). However, the similarity between drumlin orientations at $M$ and I suggests that at least part of $\mathrm{M}$ reflects the sediment deposited beneath a supraglacial trough. Because the extcnt of a subglacial lake in the Superior basin, if one existed, is unknown, it could have extended outside the boundary of the present lake. A supraglacial trough could issue from any point above the unknown subglacial lake boundary.

The southwestern part of moraine $\mathbf{M}$ appears, at first glance, to mark the boundary between two flow fields, one on the north side of the lake and the other on the south side. These flow fields apparently converge on the lee side of the lake. This interpretation is probably incorrect. As previously shown, the flow issuing from the lee side of a subglacial lake diverges and this divergent flow pattern is evident in the second flow field.

Figure 6 sketches part of a possible subglacial lake and 


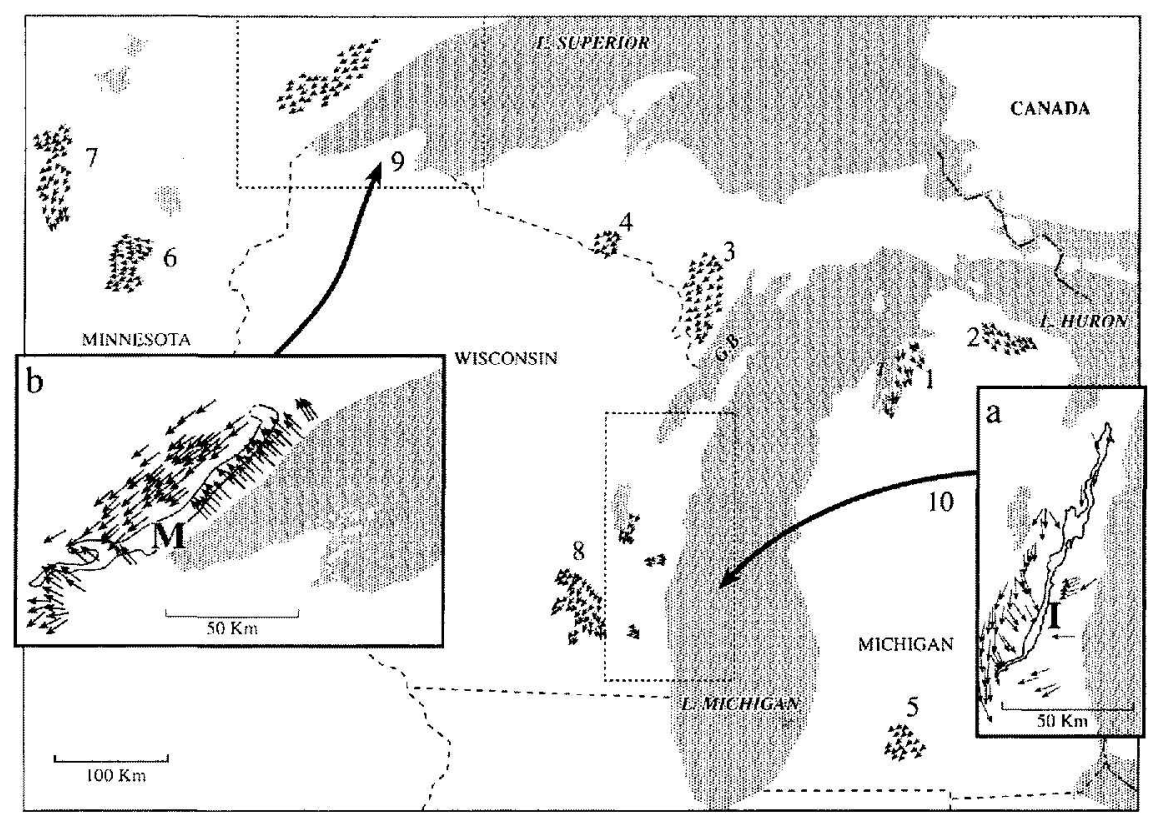

Fig. 5. Prominent drumlin fields in north-central U.S.A. afler Mills (1987). Shaded areas are contemporary lakes. Arroxes indicate drumlin orientations and extent of fields, from Flint and others (1959). Inserts ( $a)$ and $(b)$ : details of boxed regions with $I$ an "interlobate" moraine and $M$ a moraine. T, Grand Traverse Bay.

corresponding ice-surface profiles which are largely consistent with the drumlin orientations of insert b. The icc-surface contours are obtained by applying the principle that contours and drumlin orientations are roughly perpendicular. $\mathbf{T T}^{\prime}$ is a segment of a possible supraglacial trough. The subglacial lake is chosen to include I.S plus a portion, $\mathrm{S}$, of the contemporary dry lake basin.

By the construction of Figure 6 the ice ramp to the right of the trough is very stcep. This is consistent with the fact that the width of the ice lid tapers strongly towards its lee end. The ice flux from the lid would then diminish towards the lec end. This effect pulls the trough $\mathbf{T T}^{\prime}$ towards the ice lid and increases $\alpha$ on the ramp.

An important difference between this case and the Lake Michigan case of Figure 4 is that the Superior basin narrows downstream, producing convergent basin flow. The flux issuing at the basin terminus could be many times greater than the corresponding flux issuing from the broad Michigan terminus. The discharge should also be greater because of the much greater basin size at the stoss end.

Why do no drumlins occur between arc ABC and the subglacial lakc (Fig. 6)? The flux should be larger there than near arc DEF where drumlins do occur. There are two possible explanations. First, the subglacial lake and ice lid could extend beyond arc $\mathrm{ABC}$. Second, there is field evidence suggesting that erosional drumlins are the result of an intermediate state of erosion. In broad regions containing both drumlinized and non-drumlinized zones, frequently the most highly eroded arcas are not drumlinized (personal communication from $\mathbf{J}$. Shaw). Evidently, very intensive erosion can erase drumlins. In Finland, many cross-cutting fan-shaped flows appear to have erascd all drumlins in their paths, while eroding new drumlins (Punkari, 1982).

Partial cxplanations are offered concerning the other drumlin fields in Figure 5. If upper Lake Michigan and upper Lake Huron had depressed ice lids, subglacial water flow would converge on these regions from up-glacier, and the discharge from these regions would diverge. Fields 1 and 2 could then be the result of discharge from these depressed regions, with flow fields diverging in the gap between Lakes
Michigan and Huron. (Note the divergent pattern of fields 1 and 2.) The drumlins of fields 3 and 4 are nearly parallel. The corresponding sheet flows appear to issue from the Lakc Supcrior basin. There is no ready explanation as to why these drumlin fields should be precisely where they are.

Fields 6 and 7 corrcspond to two shcet flows which converge strongly. This could be the result of an ice-marginal effect, flow convergence towards a supraglacial drainage channcl or trough. Erosional processes in fields 5-8 may

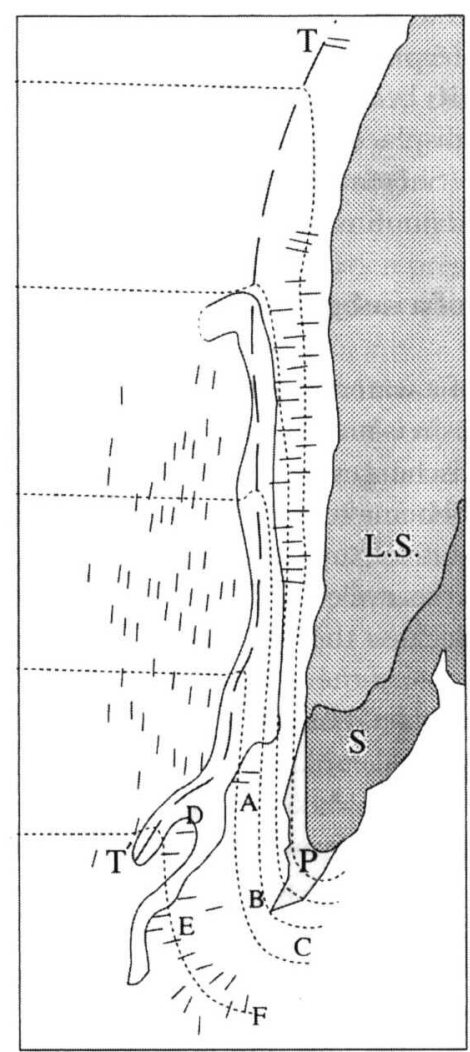

Fig. 6. Ice-sheet profiles near elevated ice lid over part of Lake Superior. LS, contemporary Lake Superior; $S+P$, proglacial lake (Flint and others, 1959); LS+S, subglacial lake and ice lid. Short line segments: drumlin orientations from Figure 5. 
also have benefited from another ice-marginal cffect. Watcrsheet velocities increase towards the margin, particularly if the margin is grounded, because of the increase in $\alpha$.

It is important to question the model's ability to predict where drumlins should not occur. There are no drumlins in the divergent-flow region of Figure 4 where $V$ is predicted to be low. Drumlins are also absent in large regions surrounding ficlds 9 and 10 (Fig. 5), where divergent flows are predicted. It is possible to find many other regions with predicted low $V$ where drumlins are absent. Note, however, that drumlins do occur in the lee of Lakes Erie and Ontario. This will be examined later.

The results are largely consistent with the fluvial model and with the assumption that the basins of lakes Michigan, Superior and Huron contained subglacial lakes, with accompanying ice lids, at the time of watcr-shcet floods. The extent of these lakes is unknown, but the Michigan basin may have been nearly full. These conclusions follow from the decent fit between predicted and actual drumlinficld locations and oricntations. The absence of drumlins in regions of predicted low $V$ (Fig. 4) adds weight.

\section{EFFEGT OF BED TOPOGRAPHY: LAKES ONTARIO AND ERIE}

Major drumlin fields occur near the boundaries of Lake Ontario (Fig. 7). Drumlins also occur in the lec of the castern shore of Lake Erie (Fig. 7), and "glacial" grooves are known on all the flat-lying limestone islands in western I ake Eric. The largest megagrooves are on Kellcys Island (Fig. 7) (Goldthwait, 1979). These grooves may be the product of fluvial erosion, evidence of a high-energy flood through the Lake Erie basin. There is no accepted model for their genesis, although erosion by ice or ice-slurry action is generally assumed (Goldthwait, 1979).

There are several related questions to answer. (1) Why do drumlin orientations near Lake Ontario vary by ncarly $180^{\circ}$ ? (2) Why are these drumlins largely confined to belts about $60 \mathrm{~km}$ wide (but up to $70 \mathrm{~km}$ ) bounding the north and south shores, with the most prominent drumlins confined to a region up to $30 \mathrm{~km}$ deep on a plateau to the southeast (Fig. 7)? (3) Why do the Finger Lakes of northern New York state occur near the southern extremities of the southern drumlin belt (Fig. 7)? (4) Can any conclusions be drawn related to Lake Erie, in particular in the genesis of the megagrooves? Most of these questions can be answered fairly satisfactorily if both the Ontario and Eric basins contained subglacial lakes at the time of a water-sheet flood. This condition is assumed in the following.

Ice-elevation contours to the north of Lake Ontario are based upon two assumptions: (1) The subglacial lakes are identical in plan form to the contemporary lakes. (2) The contours relate to the ice-surface profile before ice displacements during the flood, with onc exception discussed bclow. Therefore, with this exception, contours are generally parallel to the lake boundary. Previous comments still apply that the extent of a subglacial lake is unknown.

Ice displacements will be shown to be very important. In Figure 7 the contours near Kingston apply to the ice surface after an assumed surge along the upper reach of the Saint Lawrence Valley into I ake Ontario. With the ice sheet presumably anchored to the Ordovician Escarpment this surge would be confined to east of the escarpment. The surge could have preceded the flood. Figure 7 shows that the highly aberrant drumlin orientations down-ylacier from Kingston are roughly orthogonal to surge-induced contour lines. A similar procedurc can be used to achicve orthogonality throughout Figure 7, but is highly artificial and is a circular argument in support of the model.

What would the situation be in the absence of subglacial lakes. The effect of a subglacial dry basin upon subglacial sheet flow is the same as the effect of a similar basin, with a depth reduction of nine-tenths, upon open-channel flow. It is likely that open-channel flow into a basin the shape of Lake Ontario and averaging about $10 \mathrm{~m}$ in depth would have little effect upon flow directions as compared to the wide variation of drumlin orientations in Figure 7.

\section{Ice displacements, damming and lake levels}

To the south of I a ake Ontario the situation is complex. Shaw and Gilbert (1990) attempted to explain the extraordinary divergence of drumlin orientations by postulating two flood events: the Algonquin which was nominally to the south, and a later Ontarian event which was southwestward along the Ontario and Erie basins. In Figure 7, these events are shown as phases $\mathbf{I}$ and $\mathrm{II}$ of a single water-shect flood. 'The switch in directions of the flood will be tied to ice displacements and consequent flood damming.

The analysis rests upon some facts. If an ice sheet is not displaced down-glacier, a subglacial water sheet of at least depth $d$ can climb over a bed obstacle of height $10 d$. Howcver, if the ice sheet is displaced down-glacier the grounded-ice topography can be radically altered (Shoemaker, 1995). Now, the water depth required to climb the bed obstacle of height $10 d$ can be less or more than $d$, depending upon the new grounded-ice profile. Regardless of whether there is ice displacement, to lift ice over an obstacle of height $d$, without grounding, requires that the water be sufficiently deep to float the ice over the obstacle. To do this, normally the head must be increased at the obstacle by damming and water back-up. There is also the possibility of dragging or pushing ice over an obstacle.

Now consider what happens when a southward-flowing water-sheet flood discharges from a subglacial Lake Ontario. To the west the steep Niagara escarpment (Fig. 7) acts as a dam, more cxactly as a sluice gatc. There is the possibility that the ice is pinned at the scarp where the relief exceeds $100 \mathrm{~m}$ in places. Pinning could be preceded by a small ice displacement which moves thicker ice onto the escarpment. Regardless, the ice is pressed against the escarpment. This action temporarily reduces $q$ scvercly.

It is important to understand how damming at the Niagara scarp affects the water level in front of the dam and in other parts of the basin. Is the water level raised to such a height that ice can be floated over the escarpment? This question is easily answered. It is sufficient and conscrvative to assume that in the basin the only contribution to $m$ in Equation (3) is from the term $\mathrm{d} y / \mathrm{d} s$ (neglect the ice and bed slopes. Onc cxample is sufficient to clarify the problem. Assume that $q=300 \mathrm{~m}^{2} \mathrm{~s}^{-1}$, a moderate flood peak value (Shoemaker, 1995). Use continuity

$$
q=y V
$$

along with Equation (2). Assume that $m=0.001$ well upstream from the basin under previously grounded ice and solve for $y$ upstream. This gives $y \approx 36 \mathrm{~m}$. Taking $85 \mathrm{~m}$ as the average depth of contemporary Lake Ontario, assume 


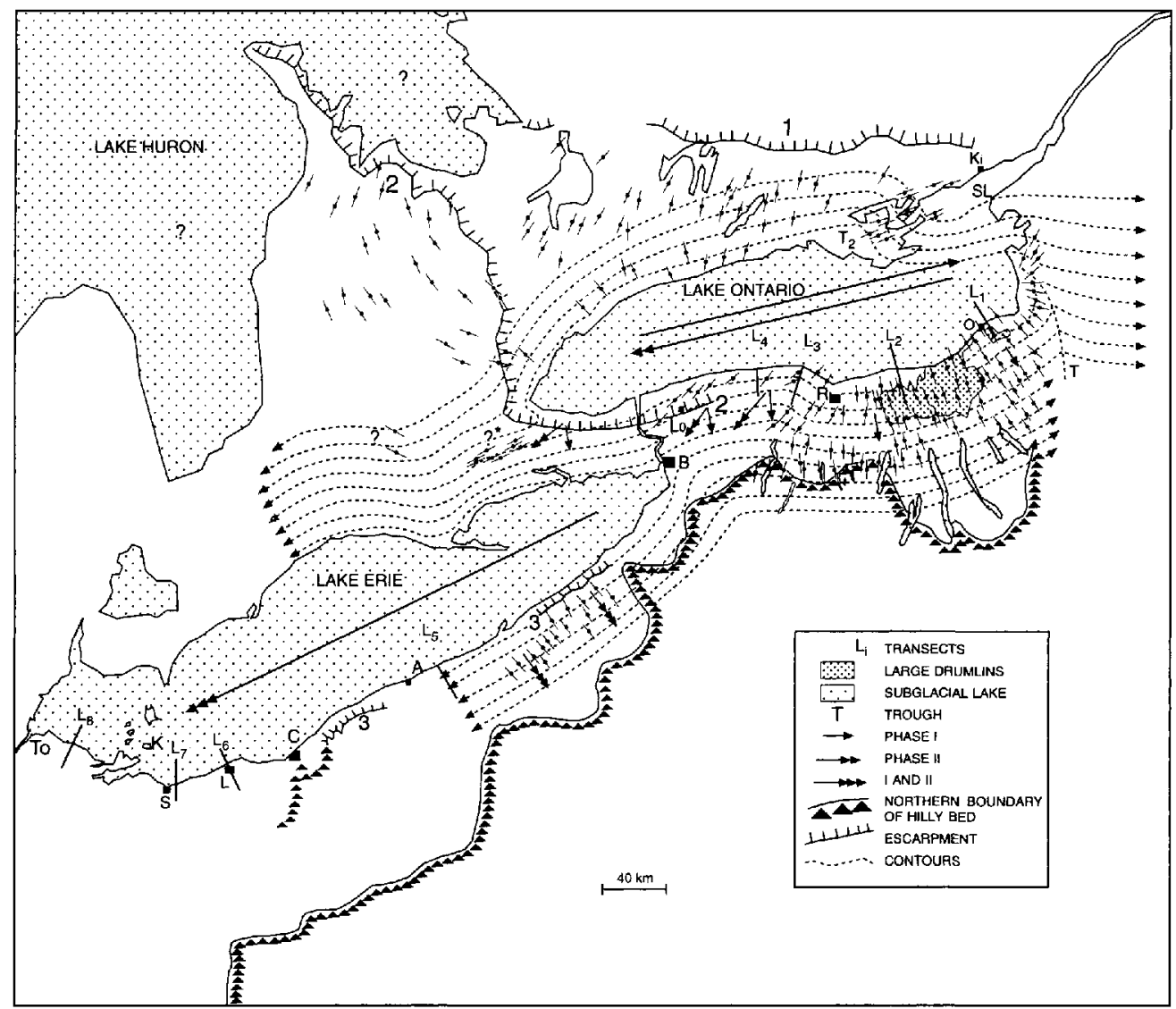

Fig. 7. Drumlin orientations near Lakes Ontario and Erie, from Flint and others (1959), Prest and others (1968) and Karrow (1989). Contour lines based upon subglacial lakes in basins. Contours in northeast corner based upon surge along St Lawerence valley into Lake Ontario. Escarpments: 1. Ordovician; 2. Niagara; 3. Erie. $\beta$ values for transects ( see Fig. 8 ):
$\mathrm{L}_{1}: \beta_{1} \approx 10^{-2}, \beta_{2} \approx 0$ $\mathrm{L}_{2}: \beta_{1} \approx 10^{2}, \beta_{2} \approx 0$
$\mathrm{L}_{4}: \beta_{1} \approx 6 \times 10^{-3}, \beta_{2} \approx 5 \times 10^{-3} ; \mathrm{L}_{5}: \beta_{1} \approx 10^{-2}, \beta_{2} \approx 6 \times 10^{-3}$;
$\mathrm{I}_{3}: \beta_{1} \approx 6 \times 10^{-3}, \beta_{2} \approx 0$
$\mathrm{I} .7: \beta_{1} \approx 0, \beta_{2} \approx 0$;
L: $\beta_{1} \approx 0, \beta_{2} \approx 0$

$$
\mathrm{L}_{6}: \beta_{1} \approx 6 \times 10^{-3}, \beta_{2} \approx 10^{-3}
$$

A, Ashtabula; B, Buffalo; C, Cleveland; K, Kelleys Island; Ki, Kingston; I, Lorain; Lo, Lockport; O, Oswego; R, Rochester; $S$, Sandusky; SL, Saini Lawrence valley; To, Toledo.

that the water depth in the basin is $121 \mathrm{~m}$, corresponding to $q=300 \mathrm{~m}^{2} \mathrm{~s}^{-1}$. Using Equations (2) and (4) again gives $m \approx 1.7 \times 10^{-5}$ in the basin. Since Lake Ontario is about $70 \mathrm{~km}$ wide the estimated change in head across the basin is about $1.2 \mathrm{~m}$. The same flux carried the entire $300 \mathrm{~km}$ length of the basin produces a head drop of about $5 \mathrm{~m}$. These values are so small they justify the crude analysis.

The conclusions are: (1) Even with damming at the Niagara scarp the water depth is nearly uniform in the basin. (2) Because the escarpment relief exceeds $100 \mathrm{~m}$ in places, pinning is very likely unless outlet damming is very extensive clscwherc. An cxccption to pinning might occur east of Lockport (Fig. 7), where the cscarpment is less steep and its relief decreases eastward. (3) Extensive damming increases the flux at undammed basin outlets. From Equations (2) and (4), $y \sim q^{\frac{3}{5}}$ so that increases in water-shect thicknesses and lake levels occur. Corresponding to a sccnario to be discussed later, output $q$ values could conceivably incrcasc by, say, a factor of ten relative to input values with a corresponding increase in $y$ above usual values by a factor of about four. In this cxtreme circumstance icc could be floated over the Niagara Escarpment.

Watcr escapes under the sluice gate but it takes time to melt or crode channels (Nye, 1976; Shoemaker, 1992b), a process which is required to enlarge the effective sluice-gate opening. Gilbert and Shaw (1994) reported on channels cut through the southeastern arm of the Ordovician limestone escarpment north of Lake Ontario (Fig. 7) where the cscarpment relief is about $45 \mathrm{~m}$. My interpretation is that thesc channcls formed over several glaciations in response to the situation just described. Channels were incised in the rock, and likcly meltcd into the ice, in response to watersheet floods being dammed at the escarpment. The assumption that a surge up the St Lawrence Valley resulted in the displaced ice topography of Figure 7, near Kingston, was partially based upon icc-sheet pinning at this escarpment.

The damming at the Niagara escarpment causcs a discharge from west to cast in the lake basin. This discharge goes over the Allegheny scarp where, initially, in the absence of major ice displacement, there is sheet flow with little or no grounding. The connection between displacement and grounding is discussed below. Thus, during at least the early stage of the phase I flood, $q$ over the Allegheny scarp is much greater than $q$ over the Niagara scarp. The drumlins east of Rochester are likely to have formed at this time because, as will be shown, the flood was dammed at the Allegheny scarp during flood phase II and the late stage of phase I. Note the orthogonality of drumlin orientations and contour lines in this region, and the general non-orthogonality to the west of Rochester (Fig. 7).

Major ice displacement accompanics large subglacial water-sheet floods unless the ice is sufficiently grounded (Shoemakcr, 1992a, b). With the removal of shear stress over most of the bed, ice-sheet cquilibrium is accomplished by 
grounding off the margins of the water sheet and grounding at bed obstacles, such as major humps or escarpments. Major ice-sheet advances, such as a $100 \mathrm{~km}$ advance of the Quinn Lake lobe over a width of $140 \mathrm{~km}$ (Dredgc, 1983), are more understandable if they are the product of watersheet floods rather than the normal surge phenomcnon associated with vallcy glacicrs.

In addition to the ice displacement assumed near Kingston in Figure 7, major ice displacements probably occurred east of the Niagara Escarpment during the phase I flood. Displacement magnitudes there are limited by four factors. First, as displaccment procceds, thin ice is replaced by thicker ice. From Figure 8 with bed slope $\beta_{1}>0$ over distance $d$, an ice summit of relief $d \beta_{1}$, relative to the ice-lid surface, develops over displacement $d$. If bed slope $\beta_{2}>0$ the ice-summit relief increases with additional displacement. $\beta_{1}$ and $\beta_{2}$ values are given for some transects in Figure 7. As the ice thickness increases, $y$ and $q$ values decrease. Provided discharge from the basin is possible by other routes, so that the basin head is not greatly increased by pervasive damming, $q$ is effectively reduced to zero after sufficient ice displacement. As beforc, rather than consider the effect of displaced ice upon a subglacial water sheet, it is easier to visualize the flood by imagining an equivalent fictitious open-channel flood on top of the grounded-ice profiles of Figure 8. To make the supraglacial flood strictly equivalent, ice thicknesses must be reduced by $10 \%$. Within this context it is morc descriptive to speak of an ice dam. It is clear that if the dam height continues to increase, eventually the equivalent supraglacial flood, of limited depth, cannot overtop the ice dam.

Second, bed or ice humps down-glacier from Lake Ontario may produce grounding (Fig. 9). Ice can be pushed over grounded patches, but as grounding increases, the sliding velocity slows until sliding is effectively eliminated. The northern boundary of very hilly terrain is shown in Figure 7. At $14 \mathrm{ka} \mathrm{BP}$ the ice-sheet terminus south of Lake Ontario is shown by Prest (1969) to coincide roughly with this boundary. At this time, large ice-sheet displacements east of the Niagara Escarpment may have been possible. Ice displacement likely produces localized grounding, even on a bed of low relief, during all but the peak-discharge flood phase. Figure 9 illustrates how cven small displaccments introduce bed and ice roughness. Rains and others (1993) discussed field evidence which indicates scour zones (zones of intense sheet flow) separated by zones of lesser or little crosion, interpreted as grounding zones.

Third, grounding near the terminus induces a deviatoric compressive stress, $\sigma_{x}^{*}$, in the ice sheet. Thus, in Figure 8 the

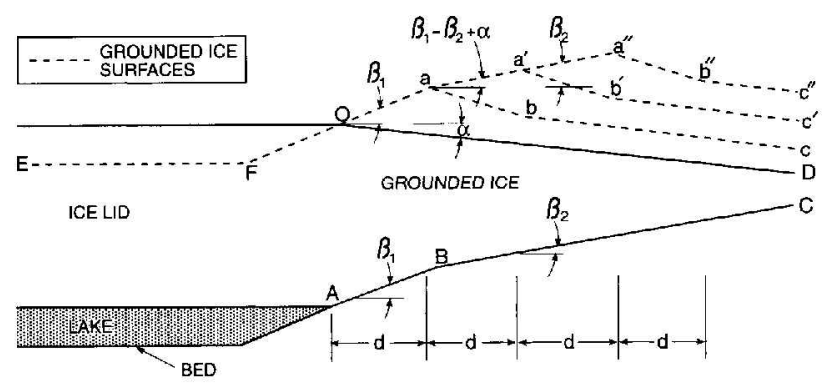

Fig. 8. Effect of displacement upon the grounded-ice profile. EFO is subglacial lake iransferred to fictitious supraglacial basin. Profile Oabc is profile after displacement d. Primed and double-primed profiles correspond to displacements $2 d$ and $3 d$, respectively. thickness of the ice dam is increased by compressive strain. By calculation, this effect can be significant if, for cxample, the effective ice temperature is $10^{\circ} \mathrm{C}$, or warmer, $\sigma_{x}^{*}$ is at least 10 bar and the duration of the water-sheet flood is at least 20 days. Gorresponding to this range of values, the ice thickness increases by at least $28 \%$.

The critical final factor which determines displacement magnitudes is the combination of the location of the subglacial lake margin and the water-sheet thickness. If the lake margin in Figure 8 extends outside contemporary Lake Ontario, length $d$ is reduced and this decreases the range of ice-dam relief values. If the entire lake basin were covered by an ice lid the dam relief at point a in Figure 8 would be eliminated. $A$ s remarked earlier, the lake size is unknown. Similarly the water-sheet thickness cannot be evaluated accurately, particularly bencath transition-zonc icc where $\alpha$ is not well known. Calculations for a range of $\alpha$ from $10^{-3}$ to $10^{-2}$ indicatc a $y$-valuc range of $14-28 \mathrm{~m}$ corresponding to $q=200 \mathrm{~m}^{2} \mathrm{~s}^{-1}$, and of $27-54 \mathrm{~m}$ at $q=600 \mathrm{~m}^{2} \mathrm{~s}^{-1}$. $q$ valucs could exceed this range, particularly if exits were blocked by ice dams.

\section{Drumlin orientations west of Rochester}

Betwecn Rochester (Ro) and Lockport (Lo) to the west, drumlin orientations are not orthogonal to contours which are parallel to the boundary of Lake Ontario (Fig. 7). However, if flood-induced ice displacements are assumed to have preceded drumlin formation, the topography of displaced icc can bc shown to bc broadly consistent with drumlin

a
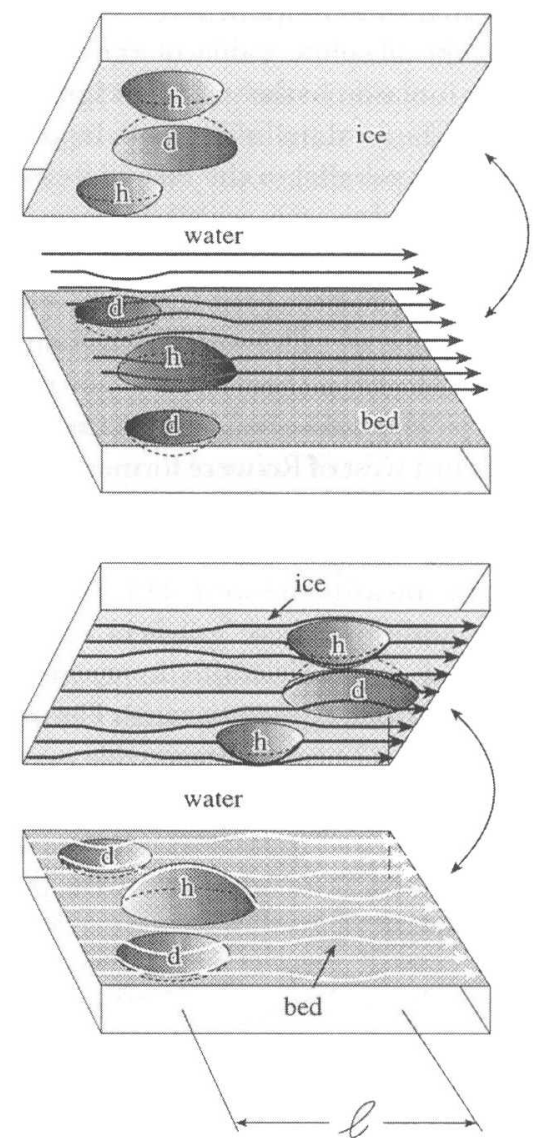

Fig. 9. Depressions d and humps h. (a) No ice displacement. Water-sheet thickness uniform and flowlines nearly planar. (b) Ice displaced distancel. Sheet is thin at h and thick at d. Flow diverges around $h$ and converges towards $d$. Grounding can occural h. 
orientations. The argument rests upon the hypothesis that these drumlins were created in a time-transgressive manner from east to west as an ice dam developed over the Allegheny scarp and progressively narrowed the gap through which the flood passed bctween Lockport and a moving eastern boundary.

From Figure 7 it is reasonable to expect that displacements would be relatively large north of the Finger Lakes and diminish to the west, because the northern boundary of hilly terrain is most distant from Lake Ontario in the Finger Lakes region. This distance narrows to the west where the effect of pinning at the Niagara Escarpment is felt.

Figure 10 outlines the idea in a simplified version. Idealized displacement profiles between Lo and Ro are shown at times $t_{i}, i=1, \ldots, 5$. Because flood discharge and watersheet thicknesses increase until the flood reaches the termination phase (Shoemaker, 1992a), maximum possible displaccments, before grounding terminates sliding, also increase with time. These maximum displacements are denoted by $d_{i}$ and, for simplicity, are assumed to be constant independent of position X. At $t_{3}$, for example, the displacement is maximum between $g_{3}$ and Ro. In the gap betwecn Lo and $g_{3}$ the displacement is assumed to vary linearly with $\mathrm{X}$. Assume that the flux and discharge are negligible on $\mathrm{g}_{3}<\mathrm{X}<$ Ro.

On transects to the west of Ro, dam relief normally increases with icc displacement, as for example along transect $\mathrm{L}_{4}$ (Figs 7 and 8). This is incorporated into the interpretation of Figure 10. Thus, the linearly varying ice displacement in the gap, $g_{i}<\mathrm{X}<$ Ro generates a component of ice-surface slope parallel to the lake boundary. For simplicity, assume that this component of icc-surface slope is proportional to the absolute value of the slope of the linear displacement function in the gap. This ignores features such as the shape of the ice dam in Figure 8. In any case, the slope of the ice surface parallel to the lake increases in the gap as the flood grows and the gap width decreases.

$\Lambda$ s an example, assume a $60 \mathrm{~m}$ thick ice dam just west of Ro, corresponding to time $t_{2}$ in Figure 10 . The average component of ice slope parallel to the lake boundary over the $85 \mathrm{~km}$ from Ro to Lo is then $7 \times 10^{-4}$, or roughly the same order as a typical $\alpha$ value beneath grounded ice. $\Lambda$ ssuming the drumlins just west of Ro were formed at this time, drumlin orientations should be in the direction of the negative gradient of the displaced ice, i.e. shifted from normal to the lake boundary towards the west. This is in agreement with Figure 7 . In addition, thesc gradient oricntations should shift more towards lake parallel as $g_{i}$ moves towards Lo (Fig. 10). This is also in agrecment with Figure 7, if the drumlins were created in at time-transgressive manner.

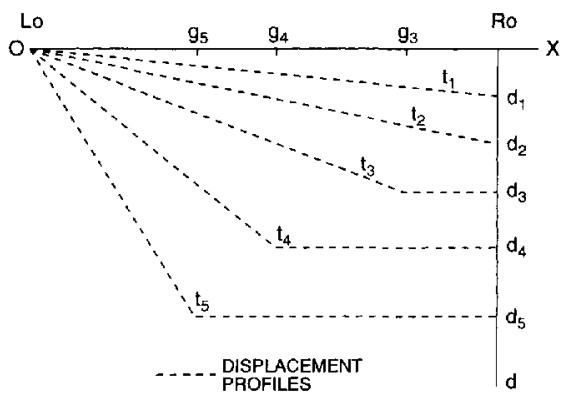

Fig. 10. Idealized ice displacements, d, between Lockport

(Lo) and Rochester (Ro) at various times $t_{i}$.

\section{Phase II}

Ice-dam build-up reduces the discharge over the $\Lambda$ llegheny scarp; erosion beneath the sluice gate increases the discharge over the Niagara scarp. At some point the second process becomes dominant and the flow direction in the Lake Ontario basin shifts from east to west. Thereafter, the flood is termed phase II. (See the later discussion under Finger Lakes for another mechanism which can terminate phase I.)

The timing of the sluice-gate enlargement is very important. There are two limiting possibilities as well as intermediatc states. First, the elapsed time for ice-dam build-up at the Allegheny scarp could be much shorter than the time for sluice-gate enlargement at the Niagara scarp. In this case, most or all exits from Lake Ontario are dammed during an interval between phases I and II. The water depth of the basin increases, perhaps by tens of meters. Subsequent opening of the sluice gate results in discharge of this storcd water west into the Lake Erie basin, the phase II flood. This scenario is consistent with the previous explanation of drumlin orientations west of Rochester and is consistent with drumlin oricntations at ? ${ }^{*}$ wcst of Lake Ontario in Figure 7.

At the other extreme, the Niagara route opens up before significant ice-dam development takes place at the Allegheny scarp. 'l'he water level of the basin is probably not affected by dams. Phase $I$ is short and discharge over the Allcgheny scarp is much less than under the previous scenario. This does not fit the evidence of high-energy flow north of the Finger Lakes where large drumlins occur, and does not explain drumlin orientations at ? ${ }^{*}$ in Figure 7.

'lhere is some theoretical support for the first model. A water-shcet flood follows the hydrograph of a channelized flood because the flood issues from a subglacial lake in channelized form (Shoemaker, 1992a). The hydrograph of a channelized flood is determined by crosion of a channel in the ice as well as the substrate (Nye, 1976). Similar erosional processes opcrate at the Niagara Escarpment to enlarge the sluice gatc. The fact that erosion starts later at the sluice gate and is likely to lag behind erosion at the subglacial lake outlet suggests that the phase II flood could occur even after the peak of the water-sheet flood. In the following it is assumed that phase 1 is long, i.c. discharge over the Niagara scarp is restricted during the time of ice-dam build-up at the $\Lambda$ llegheny scarp.

\section{The bed-profile effect upon velocities}

The largest drumlins near Lake Ontario are located east of Rochester, in a field up to $30 \mathrm{~km}$ deep down-glacier, but averaging about $20 \mathrm{~km}$ (Fig. 7). If a water shect persisted during a displacement up to $30 \mathrm{~km}$ it is possible to show that water velocities much higher than normal existed over this field.

First, consider if a water shect can be maintained during a $30 \mathrm{~km}$ displacement, or does ice-dam build-up terminate sheet flow? As an example refer to transect $\mathrm{L}_{2}$ in Figure 7 , where $\beta_{1} \approx 10^{-2}, \beta_{2} \approx 0$ and $d \approx 7.5 \mathrm{~km}$ in Figure 8 and the elevation of point $B$ relative to $A$ is $79 \mathrm{~m}$. Thus the relief at summit a is $79 \mathrm{~m}$ rclative to the surface of the icc lid. The maximum summit relief remains nearly constant for a displacement rangc of $7.5-28.5 \mathrm{~km}$, or roughly the extcnt of the drumlin field. Down-glacier from $28.5 \mathrm{~km}$ the bed rises, so the ice-dam summit clevation grows for a displacement exceeding $28.5 \mathrm{~km}$.

It would appear that for a water sheet to persist during a displacement up to $28.5 \mathrm{~km}$, the watcr depth during flood 
maximum at point $A$ in Figure 8 must be $>79 \mathrm{~m}$. However, bccausc $\rho_{\mathrm{i}} / \rho_{\mathrm{w}} \approx 0.9$ this critical depth is decreased to about $71 \mathrm{~m}$. As noted, the fictitious supraglacial flood is equivalent to the subglacial flood if ice thicknesses are reduced by $10 \%$. Is a subglacial flood depth at $A$, or fictitious supraglacial flood depth at 0 , of at least $71 \mathrm{~m}$ reasonable? There are two points to consider. First, if the subglacial lake lies outside the boundary of contemporary Lake Ontario by $3 \mathrm{~km}$, for example, $d$ is reduced by $3 \mathrm{~km}$ and the required minimum water depth at $\mathrm{A}$ (or O) is reduced $1042 \mathrm{~m}$, which is well within calculated sheet thicknesses. Second, assuming the discharge out of the basin is restricted at the Niagara Escarpment and with a dam evolving at the Allegheny Escarpment basin, water-depth values increase, as previously noted. Only if this occurs can the discharge out of the basin increase to roughly balance the discharge into the basin. Rough equality must be maintained, recognizing that there is basin storage. $\Lambda \mathrm{n}$ additional basinhead increase by $20 \mathrm{~m}$ when outflow is most impeded is not unreasonable. A $10 \mathrm{~m}$ incrcase brings the required minimum additional head at $A$ due to water-sheet flow to $32 \mathrm{~m}$ in the example. A water sheet which reaches about $30 \mathrm{~km}$ down- glacier from Lake Ontario and which persists during an ice displacement of about $30 \mathrm{~km}$ cannot be ruled out.

Figure 8 illustrates how ice with a gradient of $\alpha$ when grounded becomes ice with a gradient of $\beta_{1}-\beta_{2}+\alpha$ when transported over a plateau with bed slope $\beta_{2}$, connected to the basin by a steep ramp of bed slope $\beta_{1}>\beta_{2}$. On transect $\mathrm{L}_{2}$ (Fig. 7) $\beta_{1}-\beta_{2} \approx 10^{2}$. From Equations (2) and (3) the corresponding water-shect velocity is doubled as compared to the velocity beneath ice with gradient $\alpha \approx 10^{-3}$. Even if $\alpha \approx 10^{2}$ the velocity is increased by $20 \%$. As noted earlier, drumlin formation is thought to be relatcd to high-vclocity flows, perhaps over a brief period. It is tempting to speculate that displacements by up to $30 \mathrm{~km}$ of stcep ice were responsible for the large drumlins east of Rochester.

\section{Finger Lakes}

The Finger Lakes (and other similar lakes) are immediatcly down-glacier from the drumlin field just considered (Fig. 7). Gilbert and Shaw (1994) reviewed evidence which points to either glacial scouring or subglacial fluvial erosion as the agent which created these basins, some of which extend below sea level. There are rcasons to expect channelized fluvial erosion where the lakes are located.

It is known that the characteristic time for existence of a water sheet decreases rapidly with increasing $\alpha$ (Shoemaker, 1994). Consequently, the switch from unstable sheet flow to stable channcl flow normally occurs first at the terminus and advances up-glacier. Channel flow is encouraged by the additional factor that the relief of bed hills exceeds $10 \mathrm{~m}$ in the Finger Lakes region and this relief increases down-glacicr. Contours of bed relief are roughly parallel to the northern boundary of large hills (Fig. 7). Thercfore, local grounding should occur in the zone extending from the Finger Lakes region to the terminus, particularly after ice displacement. Displacement brings the mechanism of Figure 9 into play, and grounding becomes more pervasive. Grounding produces preferred flood paths which develop into channels. Because large channels grow at the expense of small ones, channels tend to become widely spaced.

Channcls can be incised either into the bed (Nyc (N) channels) or into the ice (Röthlisberger ( $R$ ) channels). Because $\mathrm{R}$ channcls move with the icc, they tend to become removed from the water source, namely, the water sheet. This factor is partially countcracted by R-channcl cxtension up-glacier, but it takes time to enlarge an $\mathbf{R}$ channel. Because their location on the bed is fixed, $N$ channels should be the preferred channcl form when the bed is easily erodible and the ice rapidly moving.

Once a bed channcl is created by one flood, it acts as a channel in a subsequent flood. This occurs to some extent even though the channcl is initially infilled by ice, because once displacement occurs, thick ice is replaced by thinner ice at the up-glacier end of the channcl and flow subsequently converges towards the channel. By this means, bed channels tend to propagate in the up-glacier direction over repeated floods.

During an outburst flood, subglacial channels operate at pressures lower than the overburden pressure until sudden channel closure occurs by ice infill (Nye, 1976). This implies that the phase I flood over the Allegheny scarp could be terminated by channel closure down-glacicr from the ice dam in Figure 8. The conjecture is that the Finger I akes may be remnant bed channels or tunnel valleys, formed by fluvial erosion near the terminus of an ice sheet (or sheets).

\section{Lake Erie}

The megagrooves on Kelleys Island and neighboring islands in western Lake Eric can be connected to the phase II flood from Lake Ontario into Lake Erie. An outline is given here. First, consider restrictions on discharge from the Lake Eric basin. To the west, betwcen Toledo and Sandusky, there are no constraints on either discharge or ice displacements (Fig. 7). To the east of Lorain the southern basin margin is highbanked with escarpments and hilly terrain (Fig. 7). Discharge should be restricted by the sluice-gate damming mechanism associated with a pinned state. Consequently, during both phases I and II there should be basin flow from east to west. During phase II the westward component of basin flux should be large, at least as far west as Kelleys Island, because the discharge into the basin from the main southward watcr shect plus the discharge from Lake Ontario have unimpeded outflow only to the west of Lorain (Fig. 7).

The Lake Erie basin is shallow. Taking an avcrage depth of $20 \mathrm{~m}$ for the contemporary lake and performing the same calculation as done previously for Lake Ontario gives $m \approx 2.3 \times 10^{4}$, as compared to $m \approx 1.7 \times 10^{-5}$ for Lake Ontario. Corresponding to this larger $m$ value and $q=300 \mathrm{~m}^{2} \mathrm{~s}{ }^{1}$, the head drop over the $320 \mathrm{~km}$ from the castern end of the lake to Kelleys Island is about $73 \mathrm{~m}$. During the phase II flood, if the westward component of basin flux is, on average, $>300 \mathrm{~m}^{2} \mathrm{~s}{ }^{1}$ the eastern lake lcvel would bc morc than $73 \mathrm{~m}$ higher than the western lake level. The megagrooves are oriented between $240^{\circ}$ and $260^{\circ}$ (Goldthwait, 1979). T' This is consistent with a flow westward in the basin and discharging down-glacier between Toledo and Sandusky (Fig. 7).

Ice displacement accounts for locally high-velocity (debris-laden) flows over these islands. The situation of the bed humps in Figure 9b applics. After icc displacement the water-sheet thickness, $y$, narrows locally over an island by the value of the island relief, about $20 \mathrm{~m}$. If flow divergence around an island does not markedly reduce $q$ over the island, Equation (4) implies that $V$ increases with $1 / y$ so that high velocities can occur over the islands. 


\section{Ice displacements in other Great Lakes basins}

Ice displacements were not included in the consideration of Lake Michigan. Nevertheless, displacement should accompany a water-sheet flood since the general broadening of the basin down-glacier (Fig. 5) limits side constraints. Ice displacement offers an alternative explanation of the lack of drumlins in the lee of Lake Michigan because an ice dam would severely restrict flow to the lee of the basin.

The case of Lake Superior is the opposite. Here the basin narrows towards the lee end (Fig. 5) so that icc displacements would be minimal and no ice dam should develop. This obscrvation is consistent with the presence of drumlins in the lee of Lake Superior.

\section{RELATED MATTERS}

Additional conclusions can be drawn. Those related to erosion and the situation at upflow-facing cscarpments arc addressed briefly. In addition, some explanation is given regarding drumlin presence in regions where subglacial lakes were unlikely and the ice topography was probably not unusual.

\section{Green Bay and Grand Traverse Bay, Lake Superior}

Figures 3 and 4 suggest that Grecn Bay and Grand Traverse Bay in Figure 5 are the products of fluvial scour from watershect floods interacting with an ice lid over the Lake Michigan basin. Major flood routes beneath supraglacial troughs coming off the upper Lake Michigan basin are predicted to exist in the approximate locations as Green Bay and Grand 'Traverse Bay (Figs 2b, 3 and 4). Because of the orientation and shape of Lake Michigan (Fig. 5), the western flood route is the preferred route. Green Bay to the west is larger than Grand Traverse Bay. Future floods should enlarge these bays, as suggested by Figure 4.

The convergent flow in the tapered western arm of Lake Superior (Fig. 5) has been noted. High flux and discharge at the lee end suggest past basin erosion and extension there from water-sheet floods. Future floods should continue this extension. On the other hand, ice displacement and flow divergence at the lee end of Lake Michigan, previously noted, should limit its cnlargement in the southcrly direction.

\section{Upflow-facing escarpments}

Rock flutings and drumlins are particularly well developed downflow from the crests of upflow-facing escarpments (Shaw and Gilbert, 1990; Raukas and Tavast, 1994). Pollard and others (1996) attributc this to vortcx generation at cscarpments. There is a related issue which has not been noted by others.

As mentioned previously, an ice sheet is pressed against an cscarpment during a water-sheet flood. Water cscaping over the escarpment does so by confined flow in narrow apertures. Because of the high local velocities the water pressure in these apcrtures is much less than the overburden pressure. Very intense localized turbulence as well as cavitation should be present. The localized nature of crosion, presumably by horseshoe vortices, is shown in Raukas and Tavast (1994, fig. 2).

If an ice sheet is floated over the escarpment by deep water, the situation on the escarpment trends towards a conventional water shect. Howcver, the shect thickness is narrow there so that velocities are still locally high, but not likely to be as high as when the sheet is pinned.

\section{Drumlins where the ice profile is not unusual}

Many drumlin fields occur outside regions of possible large subglacial lakes. Two examples are considered to illustrate that other mechanisms, besides unusual ice-sheet topography, may be present in drumlin formation.

(a) Drumlin fields nearly cover Finland and the Karelia and Kola peninsulas (Punkari, 1982). These ficlds are generally fan-shaped and were evidently formed at different times because fans are truncated by overlying fans (Punkari, 1982). If each fan ficld is the result of a flood, one must first explain why there were more than a dozen floods. Second, because most of the drumlin fields exceed $200 \mathrm{~km}$ in the direction of ice flow, ice displacement can be ruled out as the agent which produced high velocities. How can high velocities over such large distances be explained? A summary of results is given here. The complete development is lengthy.

The evidence is consistent with a number of supraglacial lakes discharging at different times to the bed by outburst floods through vertical channels, similar to conventional outburst floods (Nye, 1976), except that the hydraulic gradient along the vertical channel is relatively large. The important results are: (1) The supraglacial lake discharges to the bed in less than l day, regardless of lake size. (2) To a first approximation, an instant subglacial lake is created which discharges down-glacicr as a water-sheet flood. A channelized flood can be ruled out because it takes time to erode channels. In addition, the "instant" subglacial lake causes ice lift-off. (3) The flood is similar to the classic open-channel dam-break flood (Henderson, 1966). Velocities are very high over the entire flood distance. (4) A fan-shaped flood results from the fact that the flood is (instantly) deep and narrow at its origin and sprcads out downstream. It is possible that the New England drumlin fields have a similar origin since interacting fans arc present.

(b) The Livingstone Lake field of very large depositional drumlins is too wide, at least $150 \mathrm{~km}$, to have its origin in a flood from a supraglacial lake and too long to be cxplained by ice displacement. At present, the best explanation is that the "surprisingly friable" (Shaw, 1983) sandstone bed produced a sand-laden water sheet which was very abrasive and which eroded the drumlin cavity molds (Shoemaker, 1995). Note that bed erosion did not create bed forms but rather produced the erosion tools.

\section{GONCLUSIONS}

It is difficult to produce examples which establish the credibility of drumlinization by water-sheet action and which also rulc out drumlinization by the conventional ice-contact model. For example, the present development explains the connection between subglacial lakes and drumlin orientations and, in some cases, field locations and drumlin size ncar thcse lakes. However, many of the results related to drumlin orientation can be transferred to the ice-contact model because the ice-surface gradient direction is the key variable in both models. There arc, howcver, scveral 
examples developed here which do not fit the conventional modcl wcll.

(1) The megagrooves on the islands in western Lake Erie are explained by the present model but represent a major puzzle to anyone trying to explain their formation by ice contact (Goldthwait, 1979). For example, high-energy water discharge westward along the Lake Erie basin has no parallel in ice flow. (2) The abrupt change in drumlin orientations at moraines I and $\mathrm{M}$ ( Fig. 5) does not require the assumption of independent lobes moving at right angles, as does the conventional model. (3) The oricntation of drumlins west of Rochester and west of Lake Erie (Fig. 7) is, in my opinion, difficult to explain by the conventional model. (4) The locations of the Finger Lakes, Grecn Bay and Grand Traverse Bay are a natural outgrowth of the present model. It is difficult to explain these locations if the basins are the product of glacial scour. (5) I can find no explanation in the literature for the absence of drumlins in the lee of Lake Michigan. The water-sheet model predicts an absence of drumlins in this and other non-drumlinized regions. (6) The explanation given here for the gencsis of the Finnish fan-shaped drumlin fields does not invoke the notion of numerous narrow ice lobes which were active during deglaciation (Punkari, 1982).

\section{ACKNOWLEDGEMENTS}

This work was supported by a grant from the Canadian Natural Sciences and Engineering Research Council. I thank the reviewers for asking some difficult questions. The editor, M. Hambrey, was of great assistance in offering detailed comments.

\section{REFERENCES}

Alden, H. C. 1918. The Quatemary goology of southeastern Wisconsin. U.S. Geol. Suri. Prof. Pap. 106

Allen, J.R.L. 1971. Transverse erosional marks of mud and rock: their physical basis and geological significance. Sediment. Geot., 5, 167-384.

Allcn, J. R. L. 1982. Sedimentary structures. Vol. 2. Amsterdam, Elscvicr. (Developments in Sedimentology 30B:

Dargahi, B. 1990. Controlling mechanism of local scouring. ASCE 7. Hydraul. Fing., 116, 1197-1214.

Dredige, L. A. 1983. Character and development of northern Lake Agassiz and its relation to Keewatin and Hudsonian ice regimes. Geol. Assoc. Can. Spec. Pap. 26, 117-131.

1)uckworth, P. B. 1979. The late depositional history ol the western end of the Oak Ridges moraine, Ontario. Can. F. Earth Sci., 16 (5), $1094110 \%$.

Dyke, A.S. and V.K. Prest. 1987. Paleogeography of northern North America, 18000-5000 years ago. Ottawa, Ont. Geological Survey of Canada, (GSC Map 1703A. Srale l: $12,500,000$ )

Flint, R. F., R. B. Colton, R. P. Goldthwait and H. B. Willman. 1959. Glacial map of the Lnited States east of the Rocky Mountains. Boulder, CO, Geological Socicty of America. SScalc $1: 1750000$ )

Gilbert, R. andJ. Shaw. 1994. Inferred subglacial meltwater origin of lakes on the southern border of the Canadian Shield. Can. ,7. Earth Sci, 31 (11), $1630-1637$.

Goldthwait, R. P. 1979. Giant grooves made by concentrated basal ice streams. f. Glaciol., $23(89), 297307$.

Henderson. F. M. 1966. Open channel flow. New York, Macmillan Co.

Kapitsa, A. P., J. K. Ridley, G. de Q. Robin, M. J. Siegert and I. Zotikov: 1996. A large decp freshwater lake bencath the ice of central Hast Antarctica. Nature, $381,6584,684686$.

Karrow; P. F. 1989. Quaternary geology of the Great Lakes subregion. In Fulton, R. J., ed. Quaternay geology of Canada and Grenland. Geology of Canada
1. Ottawa, Ont., Golngical Survey of Canada; Boulder, CO, Geological Soricty of America, 326-350. The Geology of Jorth America K-l.

Kemmis, T.J. 1991. Glacial landforms, sedimenology and depositional encironments of the Des Moines Lobe, northern Iowa. Ph.D. thesis. University of Iowa.)

Kor, P. S. G., J. Shaw and D. R. Sharpe. 1991. Erosion ol bedrock by subglacial meltwater, Georgian Bay, Ontarin: a rrgional vicw: Can. 7. Earth Sci, 28 4 ), 623-642.

Mills, H. H. 1987. Morphometry of edrumlins in the northeastern and northcentral USA. In Menzies, J. and J. Rose, eds. Drumlin Symposium. Rotterdam, A.A. Balkema, 131-147.

Nye, J. F. 1976. Water flow in glaciers: jökulhlaups, tumnels and veins. I. Glaciol. $17(76), 181-207$

Paterson, W. S. B. 1994. The physics of glaciers. Third edition. Oxford, rts, Fisevier. Pollard, A., N. Wakarani andJ. Shaw. 1996. Genesis and morpholegy of (mosional shapes associated with turbulent flow over a forward-facing step In Ashworth, P. J., S. J. Benne1, J. I. Best and S. J. Mcl colland, eds Cheterent flowe structures in open channels. Chichester, etc., John Wiley and Sons. $249-265$.

Prest, V. K. 1969. Retreat of Wisconsin and recent ice in North America. Geol. Surz. Can. Map 1257 A.

Prest, V. K., D. R. Grant and V. N. Rampton. 1968. Giacial map of Canada. Ottawa, Ont., Geological Survey of Canada. GSC Map 1253 A, Scale $1: 5,000,000$.

Punkari, M. 1982. Glacial geomorphology and dynamics in the eastern parts of the Baltic Shield interpreted using Landsat imagery. Photogramm. 7. Finland, 9(1),77-93.

Rains, B., J. Shaw, R. Skoyc, D. Sjogren and D. Kvill. 1993. Late W'isconsin subglacial megaflood paths in Alberta. Geologi, 21 (4;,323-326.

Raukas, A. and F. 'lavast. 1994. 1)rumlin location as a response to bedrock topography on the southeastern slope of the Fennoscandian Shicld. Sediment. Geol., $91(1-4), 373-382$.

Shabtaie, S. and C. R. Bentley. 1988. Ice-thickness map of the West $A$ ntaretic ice streams by radar sounding. Ann. Glaciol, 11, 126-136.

Sharpe, D. R. and J. Shaw. 1989. Erosion of bedrock by subglacial meltwater, Cantley, Quebec. Geol. Soc. Am. Bull., 101 (8), 1011-1020.

Shaw J. 1983. I)rumlin formation related to inverted melt-water crosional marks. 7. Glaciol., 29(103), 461-479.

Shaw, J. 1988. Subglacial erosional marks, Wilton Creek, Ontario. Can. If Earth Sci, $25(8), 12561267$.

Shaw, J. 1994. Hairpin erosional marks, horseshoe vortices and subglacial erosion. Sedimenl. Geol., 91 1 4), 269283.

Shaw, J. 1996. A meltwater model for Laurentide subglacial landscapes. $I n$ McCann, S. B. and D. (. Ford, eds. Geomorphology sane fromtieres. Chichester, ets., John Wilcy and Sons, 181-236.

Shaw, J. and R. Gilbert. 1990. Evidence for large-scale subglacial meltwater flood events in southern Ontario and northern Vew York State. Geologn, $18(12), 1169-1172$.

Shaw, J. and D. R. Sharpe. 1987. Drumlin formation by subglacial meltwater erosion. Can. 7. Earth Sci., 24 (11), 2316-2322

Shaw, J., D. Krill and B. Rains. 1989. Drumlins and catastrophic subglacial floods. Sedimenl. Geol., 62/3 4), 177202.

Shoemaker, E. M. 1991. On the formation of large subglacial lakes. Can. . Earth Sci., 28(12), 19751981

Shoemaker, E. M. 1992a. Subglacial floods and the origin of low-relief icesheet lobes. f. Glaciol., 38(128, 105112.

Shoemaker, E. M. 1992b. Water sheet outburst floods from the Laurentide ice sheet. Can. 7. Earth si., 296, 12501264.

Shoemaker, E. M. 1994. Correspondence. Reply to comments on "Subglacial floods and the origin of low-relief ice-sheet lobes" by J. S. Walder. If. Glaciol, 40 134$), 201-202$

Shoemaker, E. M. 1995. On the meltwater genesis of drumlins. Boreas, 24:1), $3-10$.

Sicgert, M. J. and J. K. Ridley: 1998. Determining basal ice-sheet conditions in the Dome $\mathrm{C}$ region of East Antarctica using satellite radar altimetry and airborne radio-echo sounding. ff. Glaciol, 44(146), 18.

Walder,J. S. 1982. Stability of sheet flow of water beneath temperate glaciers and implications for glacier surging. 7. Glaciol, 2899, 273293.

Valder, J. S. 1994. Correspondence. Comments on "Subglacial floods and the origin of low-relief ice-sheet lobes" by E. M. Shoemaker. 7. Glarin., $40(134), 199-200$ 